DOI: $10.2478 / \mathrm{v} 10025-010-0036-3$

\title{
Ionic deposition and chemistry of soil solutions in a forested study area in the Chojnów Forest District in the years 2004-2007
}

\author{
Anna KOWALSKA, Magdalena JANEK
}

Forest Research Institute, Forest Site Science Department, Sękocin Stary, ul. Braci Leśnej 3, 05-090

Raszyn; e-mail: a.kowalska@ibles.waw.pl,m.janek@ibles.waw.pl

\begin{abstract}
The study was carried out in the years 2004-2007 in a permanent observation plot established in a pine tree stand growing in a mixed fresh coniferous forest habitat of the Chojnów Forest District. Analyses pertained to the deposition of mineral compounds delivered to soil with bulk precipitation in the open field and throughfall and to chemical compositions of soil solution at a depth of $25 \mathrm{~cm}$ and $50 \mathrm{~cm} . \mathrm{pH}$, electrical conductivity and concentrations of $\mathrm{Ca}, \mathrm{Mg}, \mathrm{Cl}, \mathrm{NO}_{3}, \mathrm{SO}_{4}, \mathrm{Na}, \mathrm{K}, \mathrm{Fe}$, $\mathrm{Mn}, \mathrm{NH}_{4}, \mathrm{PO}_{4}, \mathrm{Zn}, \mathrm{Cd}, \mathrm{Cu}$, and $\mathrm{Pb}$ were analysed in precipitation and in soil solution samples.

Total load of ions under the canopy of pine trees ranged between 47 and $61 \mathrm{~kg} \cdot \mathrm{ha}^{-1} \cdot \mathrm{year}^{-1}$. Acidifying ions $(\mathrm{N}+\mathrm{S}+\mathrm{Cl})$ contributed in $51 \%$ to the total ionic load (in $\mathrm{mol}_{\mathrm{c}} \cdot \mathrm{ha}^{-1} \cdot \mathrm{year}^{-1}$ ) while base ions $(\mathrm{Ca}+\mathrm{Mg}+\mathrm{Na}+\mathrm{K})$ in only $36 \%$. Respective percentage contribution in bulk precipitation was $69 \%$ and $19 \%$.

No relationship was found between the chemical composition of soil solutions (at both depths) and the chemical composition of precipitation waters. Analysed soil solutions were acidic (average $\mathrm{pH}$ at the depth of $25 \mathrm{~cm}$ and $50 \mathrm{~cm}$ was 4.3 and 4.4, respectively) and the molar ratio of the sum of base cations $(\mathrm{Ca}, \mathrm{Mg}$, and $\mathrm{K})$ to $\mathrm{Al}$ in the majority of examined samples from the upper soil layer, was much lower than 1 . This is the evidence of low buffering capacities of analysed soil in relation to acidifying loads and indicates a potential threat for the pine stand stability.
\end{abstract}

Key words: bulk precipitation, deposit, flux, load, soil solutions, soil water, throughfall, throughfall precipitation

\section{INTRODUCTION}

Atmospheric precipitation is an important pathflow of ions to the environment. Precipitation in forested areas is modified in tree crowns and reach the substratum in the form of throughfall. Numerous studies confirm that forests act as air filters due to their roughness and retention of air pollutants by tree crowns. This phenomenon refers to atmospheric aerosols: airborne dispersed liquid and solid particles of natural (i.e. molecules of pulverised soils and weathering rocks) and anthro- 
pogenic (metal compounds, aromatic hydrocarbon, etc.) origin. Horizontal deposition is the higher the higher and more developed is the flora growing in the site (ZIMKA and STACHURSKI, 1996; MAŁEK, 2002; BŁAŚ and SOBIK, 2004).

Deposition of sulphates, nitrates and chlorides reacting with solid phase of the soil induces leaching of cations and soil acidification. Rainfall components that reach the soil influence soil solutions chemistry and soils themselves and affect numerous soil processes (HANSEN et al., 1994; AVILA et al., 1995; BREDEMEIER et al., 1995; HALLGREN LARSSON et al., 1995; LABETOWICZ, 1995; BEIER et al., 1998; KREUTZER et al., 1998; OSTROWSKA et al., 1998). As soil solutions are the main carrier of ions migrating downwards through the soil profile, surface and ground waters may be contaminated by airborne elements (LASKOWSKI et al., 1995).

The aim of this paper was to estimate changes of stand throughfall depositionin pine forest floor in relation to deposition in the open field and to identify the effect of these depositions on the chemistry of soil solutions in forest stand.

\section{STUDY SITE AND METHODS}

Permanent observation plot located in the Chojnów Forest District was described in KOWALSKA and JANEK (2009). Single-storey pine stand covers gleyic arenosol derived from glacio-fluvial deposits. The soil reaction in the humus layer (fresh moor type) is strongly acidic $-\mathrm{pH}$ in the $\mathrm{CaCl}_{2}$ extract is 3 . The acidification decreases down the soil profile $-\mathrm{pH}$ at the depth of $40-80 \mathrm{~cm}$ is $4.2-4.4$.

The study plot was established in 2003 and regular surveys started in January 2004. Studies were carried out in agreement with the standards of European forest environmental monitoring which is realised in the Forest Research Institute (Manual..., http:). Water amount and chemical composition of bulk precipitation, throughfall and soil solutions were analysed bi-weekly from January 2004 to the middle of 2005 and at monthly intervals later on. In the beginning, stemflow was also analysed but due to the character of tree stand (dominated by pine trees) resulting in the minor contribution of this type of precipitation to ionic deposition, the analyses were terminated in the middle of the year 2005 .

The load of mineral compounds was calculated based on the amount and chemical composition of bulk precipitation and throughfall. The methods of analysing both types of precipitation were described in KOWALSKA and JANEK (2009).

Soil solutions were sampled with the quartz-teflon suction lysimeters PRE$\mathrm{NART}^{\circledR}$ by applying the vacuum of ca. $72 \mathrm{kPa}$. The lysimeters were evenly spaced along the diagonal of the study plot at depths of $25 \mathrm{~cm}$ and $50 \mathrm{~cm}$. Samples were collected twice a month to the middle of the year 2005, then once a month with a break during frosts when there was a risk of damage of glass elements of the sampling system by freezing water. 
Samples were transported to the laboratory immediately after collection where, on the sampling day, their volume was measured by weighing, electrical conductivity by the conductometric method, and $\mathrm{pH}$ by the potentiometric method. Remaining part of the sample was filtered through membrane filters with pore size of $0.45 \mu \mathrm{m}$ and then divided into two sub-samples: one preserved with the addition of nitric acid ( 0.5 part of acid per 100 parts of water). Concentrations of $\mathrm{Ca}, \mathrm{Mg}$, $\mathrm{Na}, \mathrm{K}, \mathrm{Fe}, \mathrm{Mn}, \mathrm{Al}, \mathrm{Zn}, \mathrm{Cd}, \mathrm{Cu}$, and $\mathrm{Pb}$ were determined by the atomic emission spectrometry method (ICP-OES). The second sub-sample was used to determine the concentration of chlorides, nitrate-nitrogen, sulphates, phosphates, and ammonium-nitrogen by the ion chromatography method. Chromatographic analyses were performed within 1-2 days after sampling, or samples were stored in a temperature below $-20^{\circ} \mathrm{C}$ for maximum 1 month. One month sample storage without freezing was allowed before the metals determination.

Results of analyses were checked by ionic balance, by comparing measured and calculated conductivity, and by calculating sodium to chloride ratios (except for soil solutions samples). Unsatisfactory test results were a basis for re-analysis of the samples. If repeated analysis did not bring any changes, the results were accepted.

Statistical calculations were made with the STATISTICA software.

\section{RESULTS}

\section{DEPOSITION OF IONS}

Bulk deposition in the open field in the years 2004-2007 averaged 2564 $\mathrm{mol}_{\mathrm{c}} \cdot \mathrm{ha}^{-1} \cdot$ year $^{-1} 46 \%$ out of which were deposited in winter months (X-III). Calcium deposition was the largest $\left(290 \mathrm{~mol}_{\mathrm{c}} \cdot \mathrm{ha}^{-1} \cdot \mathrm{year}^{-1}\right)$ among the alkaline metal ions followed by sodium, magnesium, and potassium $\left(90,67\right.$, and $48 \mathrm{~mol}_{\mathrm{c}} \cdot \mathrm{ha}^{-1}$, respectively; Tab. 1). Mean annual load of mineral nitrogen in precipitation reached $979 \mathrm{~mol}_{\mathrm{c}} \cdot \mathrm{ha}^{-1}$. Ammonium-nitrogen constituted $67 \%$ of that amount. The load of sulphate-sulphur and chlorides was substantially smaller: 608 and 184 mol $_{c} \cdot$ ha $^{-1}$, respectively.

Stand throughfall deposition recorded in the study plot differed greatly from that in bulk precipitation (Tab. 1). During four years of the study it varied between 2411 and $3377 \mathrm{~mol}_{\mathrm{c}} \cdot \mathrm{ha}^{-1}$. Respective annual loads ranged between 47 and 61 $\mathrm{kg} \cdot \mathrm{ha}^{-1}$. The average sum of ions under canopies was $2717 \mathrm{~mol}_{\mathrm{c}} \cdot \mathrm{ha}^{-1} \cdot \mathrm{year}^{-1}$ out of which $1600 \mathrm{~mol}_{\mathrm{c}} \cdot \mathrm{ha}^{-1}$ fell in winter months. Annual stand throughfall deposition was larger than bulk deposition by only $5 \%$. In the summer half-year the deposition under canopies amounted to $82 \%$ of the deposition in bulk precipitation whereas in the winter half-year $-132 \%$. 
Table 1. The load of ions in summer, winter, and the whole year in bulk precipitation (BP) and throughfall (TF) (in $\mathrm{mol}_{\mathrm{c}} \cdot \mathrm{ha}^{-1}$ ) based on averaged four-year data (2004-2007)

\begin{tabular}{l|c|c|c|c|c|c}
\hline \multirow{2}{*}{ Component } & \multicolumn{3}{c|}{$\mathrm{BP}$} & \multicolumn{3}{c}{ TF } \\
\cline { 2 - 7 } Load & $\mathrm{IV}-\mathrm{IX}$ & $\mathrm{X}-\mathrm{III}$ & $\mathrm{I}-\mathrm{XII}$ & $\mathrm{IV}-\mathrm{IX}$ & $\mathrm{X}-\mathrm{III}$ & $\mathrm{I}-\mathrm{XII}$ \\
$\mathrm{H}$ & $\mathbf{1 3 8 7}$ & $\mathbf{1 1 7 7}$ & $\mathbf{2 5 6 4}$ & $\mathbf{1 1 3 1}$ & $\mathbf{1 5 8 5}$ & $\mathbf{2 7 1 7}$ \\
$\mathrm{Ca}$ & 3 & 62 & $\mathbf{6 5}$ & 87 & 153 & $\mathbf{2 4 0}$ \\
$\mathrm{Mg}$ & 171 & 119 & $\mathbf{2 9 0}$ & 194 & 208 & $\mathbf{4 0 2}$ \\
$\mathrm{Na}$ & 41 & 26 & $\mathbf{6 7}$ & 101 & 91 & $\mathbf{1 9 2}$ \\
$\mathrm{K}$ & 35 & 55 & $\mathbf{9 0}$ & 41 & 69 & $\mathbf{1 1 0}$ \\
$\mathrm{Al}$ & 31 & 17 & $\mathbf{4 8}$ & 160 & 109 & $\mathbf{2 6 9}$ \\
$\mathrm{Cl}$ & 3 & 14 & $\mathbf{1 7}$ & 14 & 23 & $\mathbf{3 7}$ \\
$\mathrm{N}-\mathrm{NO}_{3}$ & 75 & 109 & $\mathbf{1 8 4}$ & 83 & 163 & $\mathbf{2 4 6}$ \\
$\mathrm{N}-\mathrm{NH}_{4}$ & 168 & 151 & $\mathbf{3 1 9}$ & 118 & 189 & $\mathbf{3 0 7}$ \\
$\mathrm{S}-\mathrm{SO}_{4}$ & 446 & 214 & $\mathbf{6 6 0}$ & 83 & 161 & $\mathbf{2 4 4}$ \\
$\mathrm{Fe}$ & 308 & 300 & $\mathbf{6 0 8}$ & 228 & 372 & $\mathbf{6 0 0}$ \\
$\mathrm{P}-\mathrm{PO}_{4}$ & 2 & 14 & $\mathbf{1 6}$ & 2 & 3 & $\mathbf{5}$ \\
$\mathrm{Mn}$ & 32 & 3 & $\mathbf{3 5}$ & 5 & 26 & $\mathbf{3 1}$ \\
$\mathrm{Cd}$ & 1.3 & 1.4 & $\mathbf{2 . 7}$ & 11 & 14 & $\mathbf{2 5}$ \\
$\mathrm{Cu}$ & 0.04 & 0.03 & $\mathbf{0 . 0 7}$ & 0.01 & 0.02 & $\mathbf{0 . 0 3}$ \\
$\mathrm{Pb}$ & 1.0 & 1.3 & $\mathbf{2 . 3}$ & 0.8 & 0.6 & $\mathbf{1 . 4}$ \\
$\mathrm{Zn}$ & 0.1 & 0.4 & $\mathbf{1 . 5}$ & 0.1 & 0.1 & $\mathbf{0 . 2}$ \\
\hline
\end{tabular}

The throughfall deposition of alkaline ions was substantially higher than in bulk deposition. Mean annual loads followed the sequence $\mathrm{Ca}>\mathrm{K}>\mathrm{Mg}>\mathrm{Na}$ with respective loads of $401,269,193$, and $110 \mathrm{~mol}_{\mathrm{c}} \cdot \mathrm{ha}^{-1} \cdot \mathrm{year}^{-1}$. Sulphate-sulphur dominated among acidifying ions $\left(600 \mathrm{~mol}_{\mathrm{c}} \cdot \mathrm{ha}^{-1}\right)$; slightly smaller was the load of nitrogen $\left(551 \mathrm{~mol}_{\mathrm{c}} \cdot \mathrm{ha}^{-1}\right)$ composed in $56 \%$ of nitrate-nitrogen. Throughfall delivered annually $246 \mathrm{~mol}_{\mathrm{c}} \cdot \mathrm{ha}^{-1}$ of chloride ions.

\section{SOIL SOLUTIONS}

Soil solutions, unavailable in frost periods, were not collected during periods of small atmospheric precipitation and in the periods of intensive transpiration (summer drought) either. Hence, the number of samples throughout the year was often limited and interpretation was based on a small number of data.

Mean annual $\mathrm{pH}$ of soil solutions was 4.3 at the depth of $25 \mathrm{~cm}$, and 4.4 at the depth of $50 \mathrm{~cm}$ (Tab. 2). The increase of $\mathrm{pH}$ with depth was accompanied by lower concentration of aluminium ions and higher ratio of the sum of base cations to aluminium ions. 


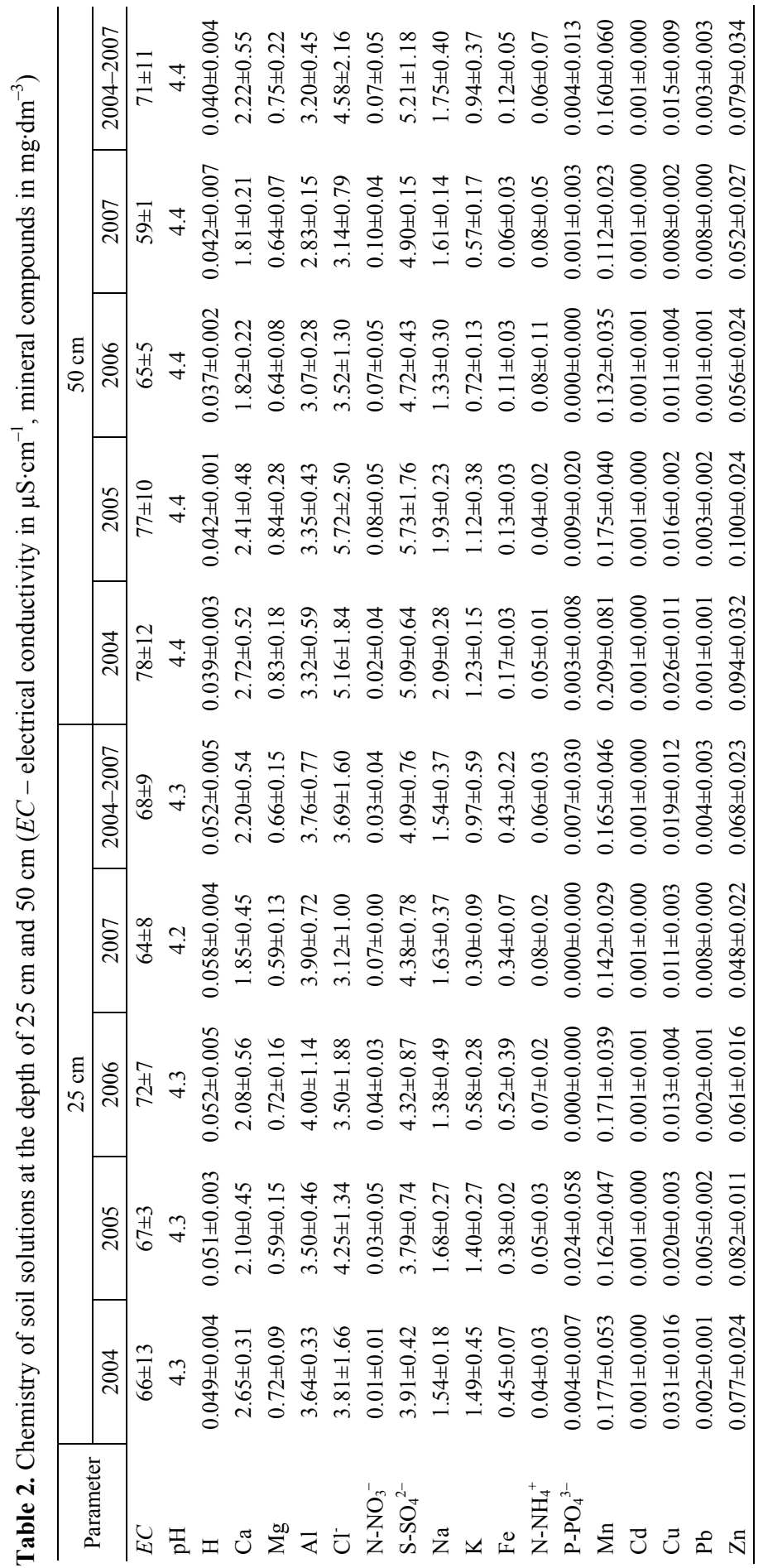


Mean conductivity at both depths was similar and amounted to ca. $70 \mu \mathrm{S} \cdot \mathrm{cm}^{-1}$. Monthly mean electrical conductivity varied from 40 to $88 \mu \mathrm{S} \cdot \mathrm{cm}^{-1}$ in upper soil layer, and from 50 to $96 \mu \mathrm{S} \cdot \mathrm{cm}^{-1}$ in the lower one. The concentration of examined ions at both depths followed the sequence $\mathrm{S}_{-} \mathrm{SO}_{4}>\mathrm{Cl}>\mathrm{Al}>\mathrm{Ca}>\mathrm{Na}>\mathrm{K}>\mathrm{Mg}$. In most cases the concentration of nitrate-nitrogen, ammonium-nitrogen, orthophosphates, cadmium and lead were below the detection limits of applied analytical methods. Hence, these values are not discussed in the paper.

\section{DISCUSSION}

\section{DEPOSITION OF IONS}

The load of protons in throughfall was substantially larger than in bulk precipitation which confirms results of other studies (JANEK, 2002; MORRIS et al., 2003). HOULE et al. (1999) found, however, that throughfall deposition of protons on a full-year basis in deciduous stand was significantly lower than in wet deposition, and in coniferous stand not significantly different from that in wet deposition in the open field. In the vegetation season coniferous as well as deciduous canopies neutralised acid deposition and retained $36 \%$ and $66 \%$, respectively, of the incoming $\mathrm{H}^{+}$.

Total annual load of ions under canopies (in $\mathrm{mol}_{\mathrm{c}} \cdot \mathrm{ha}^{-1}$ ) calculated as a mean of four-year data exceeded by ca. $5 \%$ the load in bulk precipitation though this was not the rule in all study years. The load of ions in spruce stand in the Augustów forest was twice as much as the load in bulk precipitation, while the load under the pine canopy was higher by only ca. 20\% (JANEK, 2002). The mean annual load in both types of precipitation in Chojnów was dominated by acidifying ions (sulphates, mineral form of nitrogen and chlorides) similarly as in studies conducted in the Borecka forest (OSTROWSKA et al., 1994). The share of acidifying ions in total load in the open field expressed in $\mathrm{mol}_{\mathrm{c}} \cdot \mathrm{ha}^{-1}$ amounted to $67 \%$, whereas base cations (calcium, magnesium, potassium, and sodium) contributed in only $20 \%$. These values in throughfall reached respectively $51 \%$ and $36 \%$. Enrichment in alkaline ions during the passage of throughfall through canopies partially balanced the input of acidifying loads.

In summer months the load of acidifying ions in bulk precipitation, in contrast to throughfall, was larger than in winter months (Fig. 1a, b). During the vegetation season in non-forested areas, the load of ammonium ions increased substantially. Their origin may be attributed to the agricultural activity. Under canopy the foregoing load was much smaller than in the winter season mainly as a result of retaining by tree crowns. During winter the throughfall deposition of sulphur, chlorides and nitrogen exceeded the bulk deposition. Long-term studies (MOFFAT et al., 2002) started in Norway in the middle of the 1980's showed the decrease of acidity and 
Summer
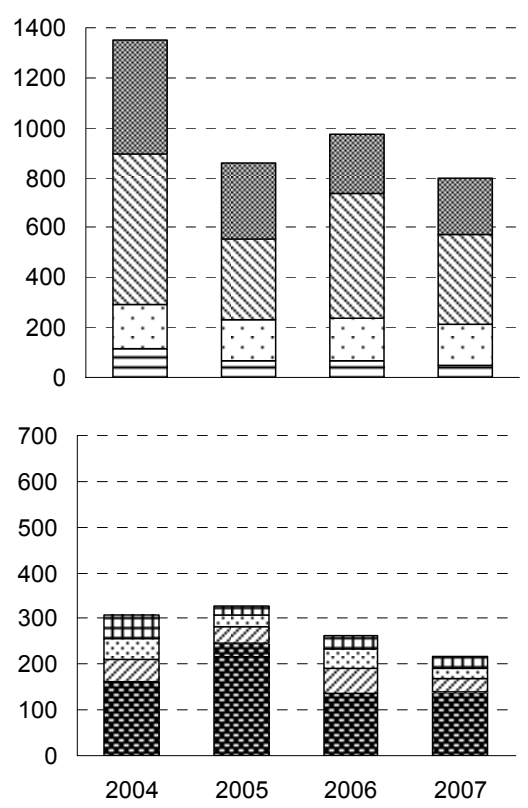

Winter
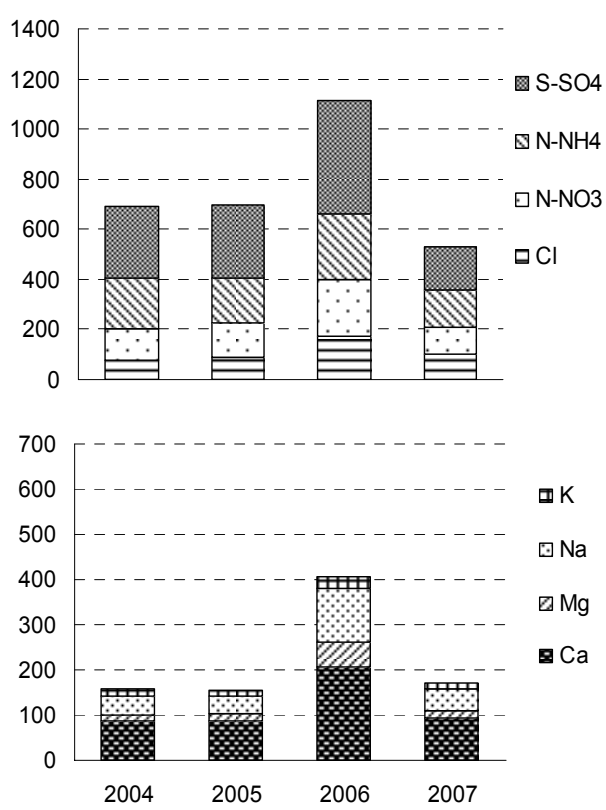

Fig. 1a. The load in $\mathrm{mol}_{\mathrm{c}} \cdot \mathrm{ha}^{-1}$ of acidifying (above) and base (below) ions in summer months IV-IX (on the left) and winter months X-III (on the right) in bulk precipitation in the years 2004-2007

of the mean flux input of some of analysed ions in throughfall and open field precipitation with the increase of acid neutralising capacity. A decrease of sulphur and mineral nitrogen deposition with the increase of nitrate-nitrogen deposition was recorded in the Netherlands (BOXMAN et al., 2008). A four-year study period in Chojnów proved to be too short to observe temporal trends of loads despite noticeable differences among particular years of study.

\section{SOIL SOLUTIONS}

Dynamic changes in the chemistry of soil solution are related to complex biogeochemical processes regulating elements transfer between solid and liquid phase, e.g. ion exchange, weathering of minerals, mineralisation. The rate and direction of changes are modified by stand and climate conditions, land use and management at present and in the past, soil treatments, condition and age of tree stands (GAWLIŃSKI and OSTROWSKA, 1993; KRÁM et al., 1997; SCHAAF et al., 1997; NIELSEN et al., 1999, NIHLGÅRD and ALAUZIS, 2002). The reduction of acidifying deposition since the close of the last century across Europe caused noticeable changes in soil chemistry reflected in the composition and properties of soil solutions. 

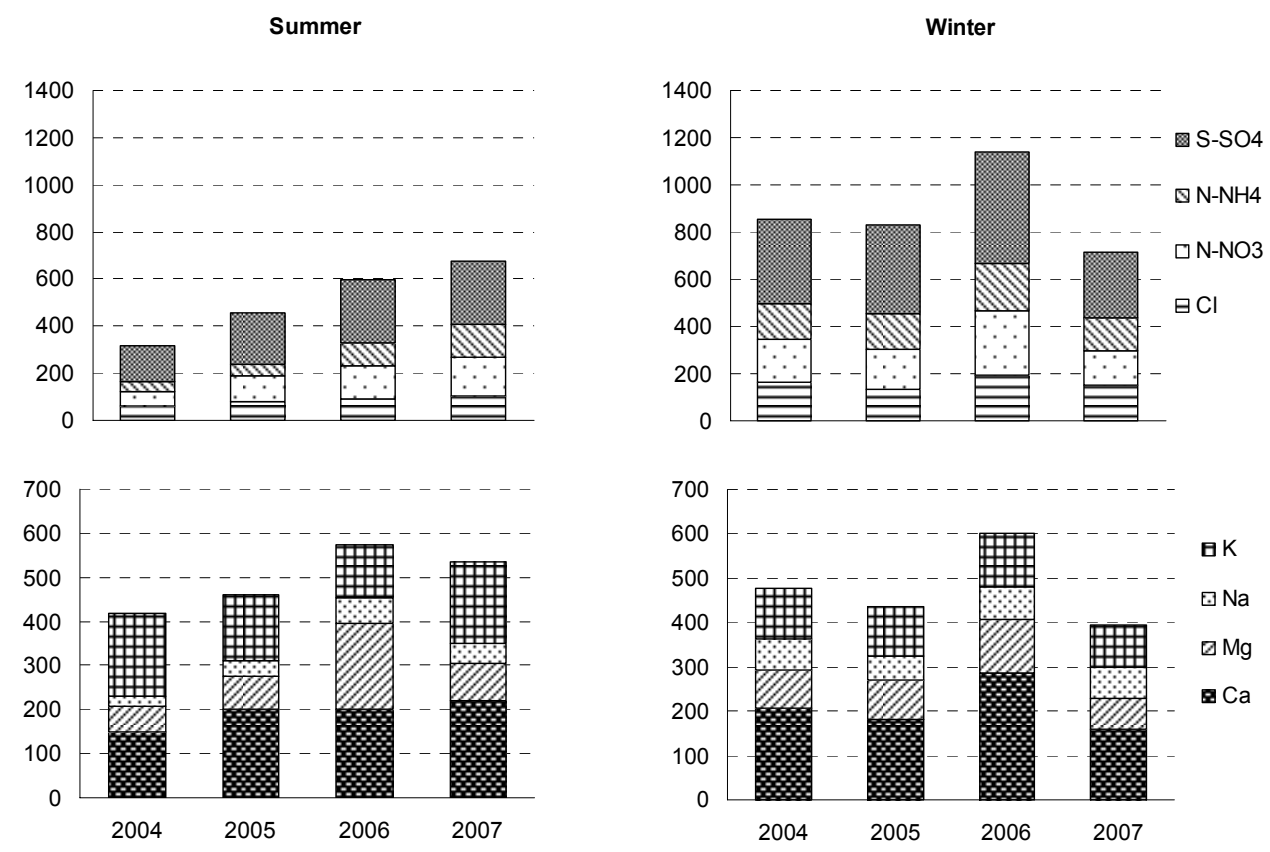

Fig. 1b. The load in $\mathrm{mol}_{\mathrm{c}} \cdot \mathrm{ha}^{-1}$ of acidifying (above) and base (below) ions in summer months IV-IX (on the left) and winter months X-III (on the right) in throughfall in the years 2004-2007

Long-term monitoring study in Norway (MOFFAT et al., 2002) demonstrated that the character of soil solutions is significantly affected by the chemistry of precipitation reaching the soil surface. This effect is especially distinct in upper soil layers where any changes, both long-term and seasonal, exhibit most intensively. In spite of decreasing input of acidifying ions soil acidification is still in progress. In the Netherlands, in pine stand, the acidification of soil solutions in upper mineral soil increases though leaching of nutrients decreased with the decreasing emission of sulphur and nitrogen. The process of acidification will be hampered when the concentration of base cations increases, which may last for many decades (BOXMAN et al., 2008). Moreover, sulphur accumulated in the soil as a result of previous emission in the regions receiving large acidifying loads in the past, may undergo a gradual mobilization (OULEHLE et al., 2006; DE VRIES et al., 2007) combined with the release of protons to soil solutions, that would enhance excessive leaching of base cations.

Soil solutions in Chojnów are dominated by sulphate and aluminium ions. Linear correlation $(R=0.87)$ revealed close relationship between sulphur content in the soil solution at the depth of $25 \mathrm{~cm}$ and $S$ deposition under the canopy, that suggests airborne origin of sulphur in the liquid phase of the upper soil layers. Further analysis of correlation indicated that the remaining chemical compounds in soil 
solutions, except for chloride concentrations $(R=0.70)$ seemed to depend neither significantly nor directly on throughfall deposition.

According to the data of the European Intensive Monitoring, below throughfall inputs of $10 \mathrm{~kg} \cdot \mathrm{ha}^{-1} \cdot \mathrm{y}^{-1}$, the leaching of nitrogen is negligible. Another factor limiting the leaching of nitrogen is a high (over 30) $\mathrm{C} / \mathrm{N}$ ratio in organic soil layers (DE VRIES et al., 2007). In Chojnów the sum of mineral nitrogen only in 2006 approached $10 \mathrm{~kg} \cdot \mathrm{ha}^{-1}$ being lower in other years and the $\mathrm{C} / \mathrm{N}$ ratio in humic soil layer ranged between 25 and 35. As no significant amounts of nitrates were found in soil solutions one may conclude that the ecosystem did not reach the maximum of its $\mathrm{N}$ retention capacity.

The soil solutions from Chojnów were acidic. Below pH 4.5 or below $25 \%$ of base saturation of the soil sorption complex (as it was the case in Chojnów) acidic deposition is mainly neutralised in the soil by Al release (DE VRIES et al., 2003). It may be the reason for high Al concentration in soil solutions in Chojnów. Free aluminium ions have strong phytotoxic properties which are, however, moderated at increasing concentrations of base cations. It is assumed that at molar ratio of $\mathrm{Ca} / \mathrm{Al}$ or $(\mathrm{Ca}+\mathrm{Mg}+\mathrm{K}) / \mathrm{Al}$ less than 1 poses a risk of damage to plant roots and negatively affects plant growth depending on species-specific plant sensitivity.

Mean annual molar ratio of $(\mathrm{Ca}+\mathrm{Mg}+\mathrm{K}) / \mathrm{Al}$ in the years 2004 and 2005 oscillated around 1 (Fig. 2). In the next years the ratio decreased and was lower in the upper than in the lower soil layers. The decline of $(\mathrm{Ca}+\mathrm{Mg}+\mathrm{K}) / \mathrm{Al}$ ratio should be mainly attributed to decreasing concentrations of $\mathrm{Ca}$ and $\mathrm{K}$ since $\mathrm{Mg}$ concentrations changed little at both soil depths (Fig. 3). Conclusions on the ecological risk resulting from exceeding the critical ratio of base cations to aluminium seem premature according to Swiss studies (WALDNER et al., 2007). However, a potential threat for the plants should be taken into consideration.

$(\mathrm{Ca}+\mathrm{Mg}+\mathrm{K}) / \mathrm{Al}$

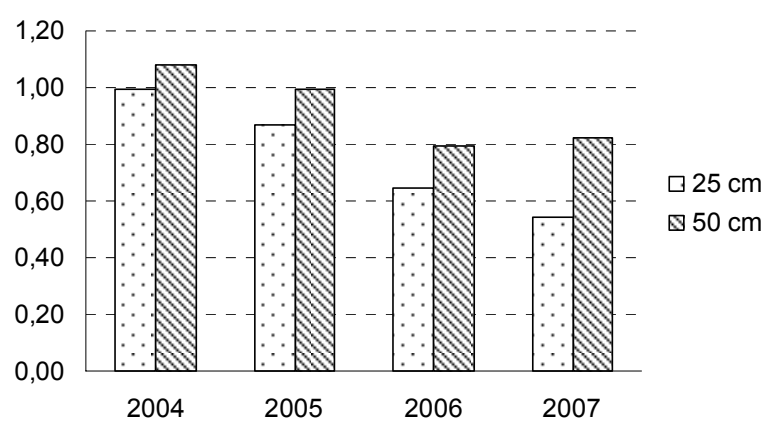

Fig. 2. Molar ratio of base cations to aluminium ion in soil solutions from the depths of 25 and $50 \mathrm{~cm}$ 
$25 \mathrm{~cm}$

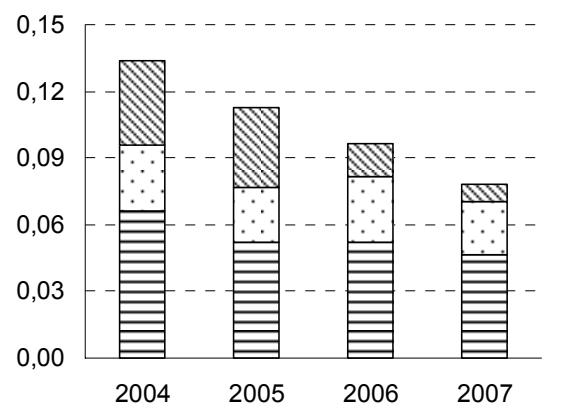

$50 \mathrm{~cm}$

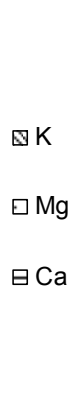

$50 \mathrm{~cm}$

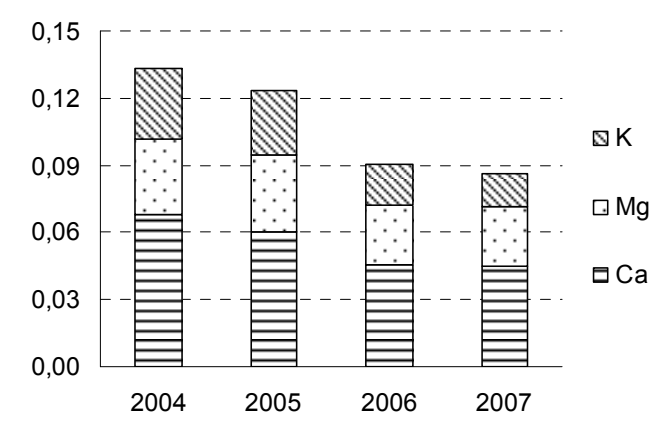

Fig. 3. Comparison of the concentrations $\left(\mathrm{mmol} \cdot \mathrm{dm}^{-3}\right)$ of base cations in soil solutions from the depths of 25 and $50 \mathrm{~cm}$

\section{CONCLUSION}

Chemistry of waters in Chojnów was studied in the period of significant reduction of sulphur emissions that started already in the 1990's. After only four years of research it is difficult to ascertain whether the ecosystem is still under deepening chemical stress caused by previous and current emissions or is recovering the equilibrium.

Total load of ions in bulk precipitation in the years 2004-2007 was 2587 $\mathrm{mol}_{\mathrm{c}} \cdot \mathrm{ha}^{-1} \cdot \mathrm{year}^{-1}$ on average. The load of ions under pine canopies was by ca. $5 \%$ larger and averaged $2717 \mathrm{~mol}_{\mathrm{c}} \cdot \mathrm{ha}^{-1} \cdot \mathrm{year}^{-1}$. The share of acidifying ions $(\mathrm{N}+\mathrm{S}+$ $\mathrm{Cl}$ ) in the total load of ions, expressed in $\mathrm{mol}_{\mathrm{c}} \cdot \mathrm{ha}^{-1}$, considerably exceeded the share of base ions $(\mathrm{Ca}+\mathrm{Mg}+\mathrm{Na}+\mathrm{K})$, both in bulk precipitation and in throughfall.

The effect of atmospheric deposition on the chemistry of soil solutions is expressed only in the concentrations of sulphates and chlorides. Analysed solutions were acidic. Mean annual $\mathrm{pH}$ was below 4.5 , and the molar ratio of the base cations (sum of $\mathrm{Ca}, \mathrm{Mg}$, and $\mathrm{K}$ ) to $\mathrm{Al}$ was in most samples far less than 1 . Along with other soil properties it is an evidence for low buffering capacity of studied soil with respect to acidifying load and indicates a potential risk for the tree stand stability.

\section{REFERENCES}

1. Avila A., Bonilla D., RodÀ F., Piñol J., Neal C., 1995. Soilwater chemistry in a holm oak (Quercus ilex) forest: inferences on biogeochemical processes for a montane - Mediterranean area. J. Hydrol., 166: 15-35.

2. Beier C., Blanck K., Bredemeier M., Lamersdorf N., Rasmussen L., Xu Y.-J., 1998. Fieldscale 'clean rain' treatments to two Norway spruce stands within the EXMAN project - effects on soil solution chemistry, foliar nutrition and tree growth. Forest Ecol. Manag., 101: 111-123. 
3. BŁaś M., SobIK M., 2004. Distribution of fog frequency in the Carpathian Mountains. Geogr. Pol., 77, 1: 19-34.

4. Boxman A.W., Peters R.C.J.H., Roelofs J.G.M., 2008. Long term changes in atmospheric N and $\mathrm{S}$ throughfall deposition and effects on soil solution chemistry in a Scots pine forest in the Netherlands. Env. Pollut., 156: 1252-1259.

5. Bredemeier M., Dohrenbusch A., Murach D., 1995. Response of soil water chemistry and fine-roots to clean rain in a Spruce forest ecosystem at Solling, FRG. Water Air Soil Pollut., 85: $1605-1611$.

6. De VRIES W., ReINDS G. J., Vel E., 2003. Intensive monitoring of forest ecosystems in Europe 2: Atmospheric deposition and its impacts on soil solution chemistry. Forest Ecol. Manag., 174: 97-115 .

7. De Vries W., van der Salm C., Reinds G.J., Erisman J.W., 2007. Element fluxes through European forest ecosystems and their relationships with stand and site characteristics. Env. Pollut., 148: 501-513.

8. GAWLIŃSKi S., OstrowsKA A., 1993. Chemizm roztworów glebowych na obszarze Stacji Kompleksowego Monitoringu Środowiska „Bory Tucholskie”. W: Monitoring Środowiska. Stacja Kompleksowego Monitoringu Środowiska Bory Tucholskie. Red. A. Ostrowska. Warszawa, IOŚ: 103-110.

9. Hallgren Larsson E., Knulst J., Malm G., Westling O., 1995. Deposition of acidifying compounds in Sweden. Water Air Soil Pollut., 85: 2271-2276.

10. HANSEN K., Beier C., Gundersen P., RASMUSSEN L., 1994. Experimental manipulations of water and nutrient input to a Norway spruce plantation at Klosterhede, Denmark: 3) Effects on throughfall, soil water chemistry, and decomposition. In: Throughfall and canopy interactions in spruce forest (by K. Hansen). Forskningsser., 8: 77-92.

11. Houle D., Ouimet R., Paquin R., Laflamme J.-G., 1999. Interactions of atmospheric deposition with a mixed hardwood and a coniferous forest canopy at the Lake Clair Watershed (Duchesnay, Quebec). Can. J. Forest Res., 29: 1944-1957.

12. JANEK M., 2002. Wpływ drzewostanów iglastych na jakość wód opadowych. Cz. 3. Dopływ depozytu do dna lasu w drzewostanach iglastych Puszczy Augustowskiej. Pr. Inst. Bad. Leśn. Ser. A, 3(942): 97-107.

13. KOWALSKA A., JANEK M., 2009. Badania jakości wód opadowych w środowisku leśnym na stałej powierzchni obserwacyjnej w Nadleśnictwie Chojnów w latach 2004-2007. J. Land Water Dev., 13a: 283-297.

14. KRÁM P., HruŠKa J., WenNer B.S., Driscoll C.T., JohnSOn C.E., 1997. The biogeochemistry of basic cations in two forest catchments with contrasting lithology in the Czech Republic. Biogeochem., 37: 173-202.

15. Kreutzer K., Beier C., Bredemeier M., Blanck K., Cummins T., Farrell E. P., Lamersdorf N., Rasmussen L., Rothe A., De Visser P.H.B., Weis W., Weiß T., Xu Y.-J., 1998. Atmospheric deposition and soil acidification in five coniferous forest ecosystems: a comparison of the control plots of the EXMAN sites. Forest Ecol. Manag., 101: 125-142.

16. LASKOWSKI R., MARYAŃSKI M., NIKLIŃSKA M., 1995. Changes in the chemical composition of water percolating through the soil profile in a moderately polluted catchment. Water Air Soil Pollut., 85: 1759-1764.

17. ŁABĘTOWICZ J., 1995. Skład chemiczny roztworu glebowego w zróżnicowanych warunkach glebowych i nawozowych. Warszawa, Fund. Rozw. SGGW: 101.

18. MAŁEK S., 2002. Changes in the chemical composition of rainfall sifted through the canopy of Spruce stands. Czas. Tech. Inż. Środ., 4-Ś. Kraków, Wydaw. PKrak.: 37-45.

19. Manual on methods and criteria for harmonized sampling, assessment, monitoring and analysis of the effects of air pollution on forests: http://www.icp-forests.org/Manual.htm

20. Moffat A. J., KvaAlen H., Solberg S., Clarke N., 2002. Temporal trends in throughfall and soil water chemistry at three Norwegian forests, 1986-1997. Forest Ecol. Manag., 168: 15-28. 
21. Morris D. M., Gordon A. G., Gordon A. M., 2003. Patterns of canopy interception and throughfall along a topographic sequence for black spruce dominated forest ecosystems in northwestern Ontario. Can. J. Forest Res., 33: 1046-1060.

22. Nielsen K. E., LadeKarl U. L., Nørnberg P., 1999. Dynamic soil processes on heathland due to changes in vegetation to oak and Sitka spruce. Forest Ecol. Manag., 114: 107-116.

23. NihlgÅRD B., AlauZIS V., 2002. Water quality in acidified areas and effects of forest management. Czas. Tech. Inż. Środ., 4-Ś. Kraków, Wydaw. PKrak.: 67-75.

24. Ostrowska A., GAwliński S., PoręBSKA G., 1998. Chemizm wód glebowych w naturalnym środowisku leśnym Stacji Kompleksowego Monitoringu Środowiska Puszcza Borecka. W: Monitoring środowiska. Pr. zbior. Red. I. Wiatr, H. Marczak. Nałęczów, Wydaw. Ekoinż.: 563-574.

25. Ostrowska A., Gawliński S., Sienkiewicz J., PoręBSKa G., 1994. Ocena chemizmu wód opadowych, powierzchniowych i glebowych na tle badań w Stacji Kompleksowego Monitoringu Puszcza Borecka. Warszawa, PIOŚ: 80.

26. Oulehle F., Hofmeister J., Cudlín P., HrušKa J., 2006. The effect of reduced atmospheric deposition on soil and soil solution chemistry at a site subjected to long-term acidification. Načetín, Czech Republic. Sci. Total Env., 370: 532-544.

27. SCHAAF W., WeISDORFER M., HUETTL R.F., 1997. Effects of long-term deposition of acidity and alkalinity on soils of Scots pine ecosystems in NE-Germany and processes of recovery. In: Acid snow and rain. Eds. K. Aoyama, K. Katoh, T. Murano, T. Pačes, Y. Taguchi. Niigata, Japan: 415-420.

28. Waldner P., Schaub M., Graf Pannatier E., Schmitt M., Thimonier A., Walthert L., 2007. Atmospheric deposition and ozone levels in Swiss forests: are critical values exceeded? Env. Monit. Assessm., 128: 5-17.

29. ZiMKA J.R., StachURSKi A., 1996. Kwaśne opady deszczu a obumieranie lasów świerkowych w Karkonoszach. W: Chemizm i oddziaływanie kwaśnych deszczy na środowisko przyrodnicze. Pr. zbior. Red. B. Walna, L. Kaczmarek, J. Siepak. Sesja naukowa, 10.06.1996. Poznań-Jeziory: $41-59$.

\section{STRESZCZENIE}

\section{Kształtowanie się depozytu jonów oraz chemizmu wód glebowych w środowisku leśnym na stałej powierzchni obserwacyjnej w Nadleśnictwie Chojnów w latach 2004-2007}

Słowa kluczowe: depozyt, ładunek, opady atmosferyczne, opady na otwartej przestrzeni, opady podkoronowe, roztwory glebowe, wody glebowe

Badania prowadzono w latach 2004-2007 na stałej powierzchni obserwacyjnej, założonej w drzewostanie sosnowym na siedlisku bór mieszany świeży w Nadleśnictwie Chojnów. Badania dotyczyły wielkości ładunku składników mineralnych docierających do podłoża wraz z opadami atmosferycznymi na otwartej przestrzeni oraz pod okapem drzewostanu, a także składu chemicznego roztworów glebowych na głębokości 25 i $50 \mathrm{~cm}$. W próbkach opadów oraz wód glebowych oznaczano $\mathrm{pH}$ i przewodność elektryczną właściwą oraz wykonywano analizy zawartości jonów: $\mathrm{Ca}, \mathrm{Mg}, \mathrm{Cl}, \mathrm{NO}_{3}, \mathrm{SO}_{4}, \mathrm{Na}, \mathrm{K}, \mathrm{Fe}, \mathrm{Mn}, \mathrm{NH}_{4}, \mathrm{PO}_{4}, \mathrm{Zn}, \mathrm{Cd}, \mathrm{Cu}$ i $\mathrm{Pb}$. 
Sumaryczny ładunek jonów pod okapem drzewostanu sosnowego kształtował się w zakresie od 47 do $61 \mathrm{~kg} \cdot \mathrm{ha}^{-1}$ rocznie. Udział jonów zakwaszających $(\mathrm{N}+\mathrm{S}+$ $\mathrm{Cl}) \mathrm{w}$ ładunku sumarycznym jonów pod okapem, wyrażonym $\mathrm{w} \mathrm{mol}_{\mathrm{c}} \cdot \mathrm{ha}^{-1}$, wyniósł $51 \%$, natomiast udział jonów alkalicznych $(\mathrm{Ca}+\mathrm{Mg}+\mathrm{Na}+\mathrm{K})$ osiagnął zaledwie $36 \%$. Wartości te $\mathrm{w}$ opadzie na otwartej przestrzeni wyniosły odpowiednio 69 i $19 \%$.

Nie stwierdzono silnego związku składu chemicznego roztworów glebowych (z obu głębokości) z właściwościami chemicznymi wód opadowych. Odczyn badanych roztworów glebowych był kwaśny (średnie pH na głębokości 25 i $50 \mathrm{~cm}$ wyniosło odpowiednio 4,3 i 4,4), a stosunek molowy sumy kationów zasadowych (Ca, $\mathrm{Mg}$ i K) do kationu $\mathrm{Al}$ w większości badanych prób z górnego poziomu glebowego był daleko mniejszy od granicznej wartości 1. Świadczy to o niewielkich zdolnościach buforowych gleb w stosunku do ładunku zakwaszającego, a także wskazuje na potencjalne zagrożenie stabilności drzewostanu.

Reviewers:

Dr. Ludmita Rossa

Dr. Józef Wójcik 